\title{
Decreased concentration of plasma leptin in periparturient dairy cows is caused by negative energy balance
}

\author{
S S Block, W R Butler, R A Ehrhardt, A W Bell, \\ $M$ E Van Amburgh and Y R Boisclair \\ Department of Animal Science, Cornell University, Ithaca, New York 14853, USA \\ (Requests for offprints should be addressed to Y R Boisclair; 259 Morrison Hall, Cornell University, Ithaca, New York 14853-4801, USA; \\ Email: yrb1@cornell.edu)
}

\begin{abstract}
Dairy cows suffer from an intense energy deficit at parturition due to the onset of copious milk synthesis and depressed appetite. Despite this deficit, maternal metabolism is almost completely devoted to the support of mammary metabolism. Evidence from rodents suggests that, during periods of nutritional insufficiency, a reduction in plasma leptin serves to co-ordinate energy metabolism. As an initial step to determine if leptin plays this role in periparturient dairy cows, changes in the plasma concentration of leptin were measured during the period from 35 days before to 56 days after parturition. The plasma concentration of leptin was reduced by $\sim 50 \%$ after parturition and remained depressed during lactation despite a gradual improvement in energy balance; corresponding changes occurred in the abundance of leptin
\end{abstract}

mRNA in white adipose tissue. To determine whether negative energy balance caused this reduction in circulating leptin, cows were either milked or not milked after parturition. Absence of milk removal eliminated the energy deficit of early lactation, and doubled the plasma concentration of leptin. The plasma concentration of leptin was positively correlated with plasma concentrations of insulin and glucose, and negatively correlated with plasma concentrations of growth hormone and non-esterified fatty acids. In conclusion, the energy deficit of periparturient cows causes a sustained reduction in plasma leptin. This reduction could benefit early lactating dairy cows by promoting a faster increase in feed intake and by diverting energy from non-vital functions such as reproduction.

Journal of Endocrinology (2001) 171, 339-348

\section{Introduction}

During the periparturient period, high yielding dairy cows experience major changes in energy metabolism (Bauman \& Currie 1980, Bell 1995, Barber et al. 1997, Bauman 2000). With the onset of lactation, the added metabolic activities of the mammary gland increase the total energy requirements by approximately fourfold. A pronounced energy deficit develops because voluntary feed intake is insufficient to meet this increased energy expenditure, and is met by mobilizing lipids from white adipose tissue (WAT) (Bauman \& Currie 1980, Bell 1995, Barber et al. 1997, Bauman 2000). Despite this shortfall, partitioning of nutrients to the mammary gland is favored, and represents over $70 \%$ of available energy (ingested and endogenous). The metabolic context of the nutritional insufficiency of early lactation is, however, different from that associated with fasting or undernutrition. First, increased demand, not decreased provision of nutrients, is the primary cause of the undernourished state in early lactation. Second, because the undernutrition associated with the onset of milk synthesis confers no direct benefits to the mother, lactation must call on additional hormonal and cellular adaptations to harness maternal energy metabolism (Bauman \& Currie 1980, Bell 1995, Vernon \& Pond 1997, Bauman 2000).

In ruminants, key adaptations of early lactation that have been identified in recent years include increased secretion of growth hormone $(\mathrm{GH})$ and decreased responsiveness of skeletal muscle and WAT to insulin (Bell \& Bauman 1997, Vernon \& Pond 1997, Etherton \& Bauman 1998). Changes in the plasma concentration of leptin, a protein hormone secreted almost exclusively by adipocytes (Zhang et al. 1994, Friedman \& Halaas 1998, Ji et al. 1998, Ahima \& Flier 2000), could also be an important adaptation, particularly given the role of WAT in support of early lactation in dairy cattle. In ruminants and other animals, leptin is synthesized in proportion to the overall degree of adiposity (Friedman \& Halaas 1998, Ahima \& Flier 2000, Blache et al. 2000, Delavaud et al. 2000, Ehrhardt et al. 2000), and acts on the central nervous system (CNS) to reduce voluntary feed intake (Friedman \& Halaas 1998, Henry et al. 1999, Ahima \& Flier 2000, Schwartz et al. 2000). During fasting, the plasma concentration of leptin is 
reduced rapidly, concomitant with changes in neuroendocrine signals that promote fasting metabolism and the attenuation of dispensable, energy-dependent functions such as reproduction and immune response (Ahima et al. 1996, 1999, Lord et al. 1998). Because leptin therapy partly reverses these adaptations in fasted animals (Ahima et al. 1996, Finn et al. 1998, Lord et al. 1998, Nagatani et al. 2000), an equally important role of leptin is to signal the energy status of the periphery to the CNS (Flier 1998, Ahima \& Flier 2000).

So far, most research on leptin has focused on its contribution to the development of obesity and diseases in humans and rodent models (Friedman \& Halaas 1998, Ahima \& Flier 2000). The role of leptin in regulating complex and dynamic changes in energy balance (EB), such as those taking place during the transition from pregnancy to lactation, has received only limited attention (Kawai et al. 1997, Brogan et al. 1999, Butte et al. 1999, Woodside et al. 2000); no information is available in dairy cattle, a species which suffers from a more intense energy deficit after parturition than do humans or rodents (Barber et al. 1997, Bauman 2000). As a first step towards understanding the role of leptin in dairy cattle, we have measured changes in the concentration of plasma leptin during the periparturient period. Our results indicate that the energy deficit of early lactation reduces leptin synthesis in WAT, and suggest roles for insulin, GH and metabolic fuels in mediating this effect of EB.

\section{Materials and Methods}

\section{Animals and design}

All experimental procedures were conducted with the approval of the Cornell University Institutional Animal Care and Use Committee. Multiparous Holstein cows (age, $3 \cdot 7 \pm 0 \cdot 8$ years; parity number, $1 \cdot 6 \pm 0 \cdot 7$ ) were housed in individual stalls, except around parturition when they were moved to individual maternity pens. The facility was lit between 0600 and $2300 \mathrm{~h}$.

Periparturient period study To study the transition from pregnancy to lactation, eight cows were used in the period between 35 days before and 56 days after parturition (day -35 to +56 relative to parturition). Cows were fed a total mixed ration (TMR) ad libitum once daily at $1100 \mathrm{~h}$. Nutrient composition of the TMR varied with the stage of pregnancy and lactation. The TMR contained 1.45 Mcal of net energy of lactation $\left(\mathrm{NE}_{\mathrm{L}}\right)$ and $125 \mathrm{~g}$ crude protein (CP) per kg of dry matter (DM) between day -35 and $-21,1.63 \mathrm{Mcal} \mathrm{NE}_{\mathrm{L}}$ and $143 \mathrm{~g} \mathrm{CP}$ per $\mathrm{kg}$ DM between day -21 and parturition, and $1.76 \mathrm{Mcal}$ $\mathrm{NE}_{\mathrm{I}}$ and $183 \mathrm{~g} \mathrm{CP}$ per kg DM during lactation (National Research Council 1989). Cows were milked thrice daily at 0900,1600 and $2300 \mathrm{~h}$.
Blood samples were obtained thrice weekly between day -28 and -9 , daily between day -9 and +7 , and on alternate days thereafter; they were collected between 0900 and $1000 \mathrm{~h}$ by coccygeal venipuncture. In addition, hourly blood samples were obtained for 26 consecutive hours on day $-33 \pm 5,+3$ and +56 via an indwelling jugular catheter. Plasma was prepared immediately and frozen at $-20{ }^{\circ} \mathrm{C}$ until analyzed. Biopsies of subcutaneous WAT were obtained from the tailhead region (Houseknecht \& Bauman 1997) at day $-32 \pm 5,-7 \pm 2$, $+3,+21$ and +56 . Variation in the time of hourly blood samples or WAT biopsy during pregnancy reflects differences between predicted and actual time of parturition. Biopsies were snap frozen in liquid nitrogen and stored at $-80{ }^{\circ} \mathrm{C}$.

Energy balance study A second study was performed to study the effects of EB in early lactation. Starting at parturition, 14 multiparous cows were either milked thrice daily (lactating) or never milked (non-lactating). From parturition until day +7 (relative to parturition), lactating cows were offered ad libitum levels of a low energy TMR (1.52 Mcal $\mathrm{NE}_{\mathrm{L}}$ and $189 \mathrm{~g} \mathrm{CP}$ per $\left.\mathrm{kg} \mathrm{DM}\right)$. Between day +7 and +33 , intake of this TMR was restricted to the amount consumed on day +7 and averaged 13.6土 $1.2 \mathrm{~kg} /$ day. During this same time-period, non-lactating cows consumed ad libitum levels of a high energy TMR $\left(1.70 \mathrm{Mcal} \mathrm{NE}_{\mathrm{L}}\right.$ and $188 \mathrm{~g} \mathrm{CP}$ per kg DM; average DM intake $=13 \cdot 4 \pm 4 \cdot 8 \mathrm{~kg} /$ day). Blood samples were collected on three different days between day +5 and +11 (week +1 ) and between day +26 and +33 (week +4 ). They were obtained by coccygeal venipuncture at $0800 \mathrm{~h}$ and processed immediately to plasma.

\section{Whole body energetics}

Dry matter intake, milk yield and aliquots of milk for composition analysis were obtained daily during the periparturient period study. During the EB study, these data were collected identically, except that milk composition was analyzed twice weekly. Energy content of milk and feeds were estimated from chemical composition (National Research Council 1989). Every week, body weights were recorded at a standard time on 2 consecutive days. These data were used to calculate individual estimates of EB (National Research Council 1989, Beam \& Butler 1997). Four percent fat-corrected milk yields were calculated according to the National Research Council (1989). To estimate changes in body fatness, two independent individuals assigned a weekly body condition (BC) score (thin $=1$, fat $=5$ ) to each cow as described previously (Beam \& Butler 1997).

\section{Analysis of leptin $m R N A$}

Total RNA was isolated from biopsied WAT by the acid guanidium thiocyanate-phenol-chloroform method, and 
quantified by absorbance at $260 \mathrm{~nm}$ (Boisclair et al. 2000). RNA quality was assessed on formaldehyde agarose gel by staining with Sybr Green II RNA stain (Molecular Probes, Eugene, OR, USA). A ribonuclease protection assay (RPA) was used to measure simultaneously leptin and glyceraldehyde-3-phosphate dehydrogenase (GAPDH) mRNA. Briefly, DNA fragments corresponding to $\mathrm{nt}+64$ to $+316(\mathrm{ATG},+1)$ of the bovine leptin cDNA (GenBank accession \#U50365), and to nt+717 to +823 of the partial bovine GAPDH cDNA (numbering relative to first nt reported in GenBank accession \#AJ000039) were subcloned into the plasmid pCR II (InVitrogen, Carlsbad, CA, USA). After linearization of each plasmid by digestion with the appropriate restriction endonuclease, leptin and GAPDH antisense RNAs were synthesized in the presence of $\left[{ }^{32} \mathrm{P}\right] \mathrm{UTP}$ and T7 RNA polymerase using a commercial kit (Maxiscript, Ambion, Inc., Austin, TX, USA). Two micrograms of total WAT RNA were analyzed using the RPA III kit (Ambion, Inc.). Protected bands (253 bp for leptin, $106 \mathrm{bp}$ for GAPDH) were resolved on $6 \%$ polyacrylamide, $7 \mathrm{M}$ urea gels. Signals were quantified by phosphorimaging using a Fujix-BioImaging Analyzer BAS 1000 (Fuji Medical Systems Ltd, Stanford, CT, USA).

\section{Analysis of metabolites and hormones}

Plasma glucose was measured by the glucose oxidase method and non-esterified fatty acids (NEFA) by the Acyl-CoA synthetase/oxidase method (Boisclair et al. 1994). Plasma leptin was assayed by a recently developed, double-antibody bovine radioimmunoassay (RIA) (Ehrhardt et al. 2000). The assay is based on a primary rabbit antibody raised against recombinant bovine leptin, and a secondary goat antibody raised against rabbit $\gamma$-globulin. Recombinant bovine leptin was used for iodination and standards. This RIA has a sensitivity of $0.5 \mathrm{ng} / \mathrm{ml}$ and a range of 0.5 to $20 \mathrm{ng} / \mathrm{ml}$. Plasma concentrations of insulin, GH and insulin-like growth factor (IGF-I) were measured by specific RIAs established in our laboratory (Boisclair et al. 1994, Beam \& Butler 1997). Plasma cortisol was determined by a commercially available RIA (Diagnostic Systems Laboratories, Inc, Webster, TX, USA). Inter- and intra-assay coefficients of variation for all assays averaged less than $8 \%$ and $9 \%$ respectively.

\section{Statistical analysis}

Data were analyzed by repeated measure models using the SAS statistical package (SAS Institute, Cary, NC, USA). For the periparturient period study, the mixed model accounted for time as the fixed effect and animal as the random effect. Because the most dramatic metabolic adaptations occur immediately before and after parturition, statistical analysis was performed on data compiled for week -4 (day -28 to -22 ), week -1 (day -8 to
-2 ), week +1 (day +2 to +8 ), week +3 (day +18 to $+25)$ and week +8 (day +50 to +57$)$. When the effect of time was significant $(P<0 \cdot 05)$, variation was partitioned between the following pre-planned orthogonal contrasts: (1) physiological state (STATE, week -5 and -1 vs week $+1,+3$ and +8 ); (2) stage of pregnancy (PREG, week -4 vs -1 ); (3) stage of lactation (LACT, week +1 and +3 vs week +8 ); (4) early lactation (E-LACT, week +1 vs +3$)$.

For the EB study, the mixed model accounted for treatment (lactating, non-lactating), time (week $+1,+4$ ) and their interaction as fixed effects, and animal as the random effect. The term animal (treatment) was used to test the significance of treatment, and the residual error term was used to test the significance of time and time $\times$ treatment.

\section{Results}

\section{Periparturient period}

Profiles of energy-related variables are shown in Fig. 1, and the orthogonal contrasts are reported in Table 1. Voluntary intake of dry matter and energy did not differ during pregnancy, resulting in similarly positive estimates of EB at week -4 and -1 (PREG, P>0.05; Table 1). Estimates of EB became negative at parturition with the onset of milk secretion (Fig. 1), and were lower during lactation than during pregnancy (STATE, $P<0 \cdot 001)$. The calculated energy deficit was maximal between week +1 and +3 (Fig. 1), and was eliminated by week +8 due to increased feed intake (LACT, $P<0 \cdot 001$ ). Consistent with these temporal changes in $\mathrm{EB}, \mathrm{BC}$ scores did not differ during pregnancy, but were lower during lactation (STATE, $P<0 \cdot 001)$. During lactation, reduction in BC scores was most rapid between week +1 and +3 (E-LACT, $P<0 \cdot 001)$. Although BC scores were lower at week +8 than in earlier lactation (LACT, $P<0 \cdot 001$ ), they did not change after week 6 of lactation (Fig. 1). Therefore, in this study, the periparturient period was characterized by positive EB during late pregnancy, negative EB after parturition, and return to energy equilibrium by week 8 of lactation.

Next we measured the plasma concentration of leptin during the periparturient period (Fig. 2 and Table 2). The plasma concentration of leptin did not differ during pregnancy (PREG, $P>0.05$ ), but was reduced by $\sim 50 \%$ during lactation (STATE, $P<0 \cdot 01$ ). Inspection of the leptin profile suggests that this reduction was initiated a few days before parturition (Fig. 2). Despite the gradual improvement in EB that occurred after the third week of lactation, the depression in the concentration of plasma leptin persisted at week +8 (LACT, P>0.05; Fig. 2). Blood samples were also obtained at hourly intervals over a $26-\mathrm{h}$ period at day $-33,+3$ and +56 (Fig. 2). Small fluctuations occurred throughout the day but they were 


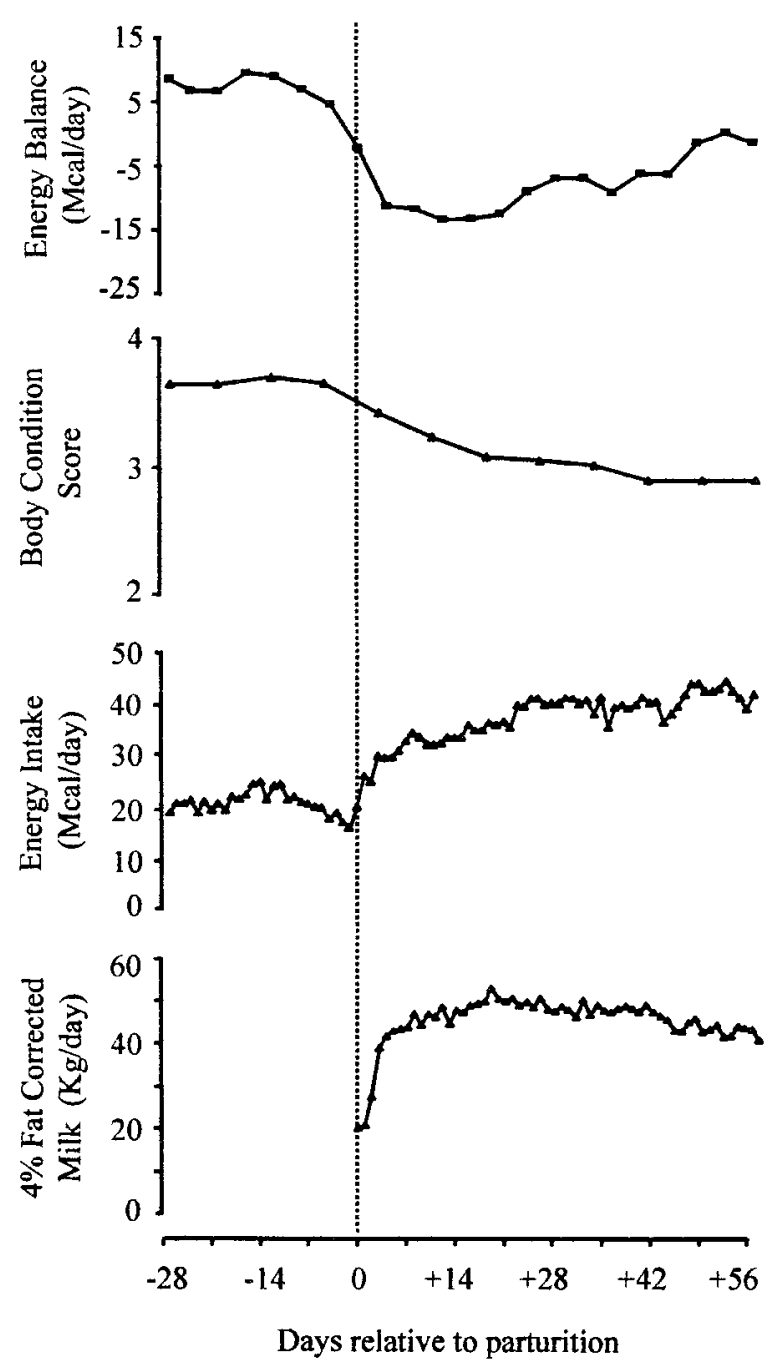

Figure 1 Changes in energy-related variables during the periparturient period. Eight multiparous dairy cows were studied during the period between 28 days before and 56 days after parturition (day -28 to +56 ). The day of parturition is indicated by a vertical line. Energy intake, milk yield and milk composition were recorded daily. These data were used to estimate EB every 4 days as described in Materials and Methods. BC was determined weekly. Pooled standard errors were $1 \cdot 1 \mathrm{Mcal} /$ day for EB, 0.1 unit for $\mathrm{BC}$ score, $0.6 \mathrm{Mcal} /$ day for energy intake and $0.9 \mathrm{~kg} /$ day for $4 \%$ fat-corrected milk yield.

not associated with time of feeding or milking, or the light:darkness cycle. Therefore, unlike rodents and humans (Schoeller et al. 1997, Ahima et al. 1998), dairy cattle do not have a higher concentration of leptin at night than during the day. This likely reflects the continuous nature of digestion and nutrient absorption in ruminants because this diurnal rhythm is entrained to the timing of meals in humans (Schoeller et al. 1997).

To determine whether changes in leptin expression during the periparturient period could account for changes in the plasma concentration of leptin, abundance of leptin mRNA was measured in subcutaneous WAT (Fig. 3). Leptin mRNA was easily detected during pregnancy and its abundance was similar at week -4 and -1 (Fig. 3). Abundance of leptin mRNA was reduced to $\sim 42 \%$ of precalving values during lactation (STATE, $P<0 \cdot 001$ ). This reduction was obvious during the first week of lactation and was sustained over the next 7 weeks (Fig. 3). Therefore, leptin synthesis was reduced immediately after parturition and did not increase with advancing lactation despite improving EB.

Finally, we examined whether changes in WAT mRNA and circulating leptin were related to changes in the concentration of plasma hormones and metabolites (Table 2). Consistent with the EB data, the plasma concentration of NEFA did not differ during pregnancy (PREG, $P>0 \cdot 05$ ), but was elevated during lactation (STATE, $P<0 \cdot 001$ ). The effect of lactation reflects primarily an increase of plasma NEFA in early lactation (E-LACT and LACT, $P<0 \cdot 001)$. The plasma concentration of insulin changed during lactation in a reciprocal fashion to the plasma concentration of NEFA (Table 2). Therefore, as shown for plasma leptin, the greatest rate of change in the concentrations of insulin and NEFA occurred around the time of parturition. However, in contrast to leptin, their concentrations returned towards pre-calving values as EB improved between weeks 4 and 8 of lactation (Fig. 1 and Table 2).

Plasma concentration of $\mathrm{GH}$ increased at parturition and remained elevated during lactation (Table 2; STATE, $P<0 \cdot 001)$. The plasma concentration of IGF-I was lower during lactation than pregnancy (STATE, $P<0 \cdot 001$ ). This reduction was initiated at the end of pregnancy (PREG, $P<0 \cdot 001$ ), and was sustained until the end of the study (E-LACT and LACT, $P>0 \cdot 05$ ). Plasma concentrations of glucose and cortisol did not differ significantly at any time (Table 2).

\section{Effect of postpartum EB}

The previous study showed that the plasma concentration of leptin was reduced at parturition, coinciding with the sudden increase in the use of endogenous lipids as a source of energy, but preceding significant depletion of WAT. This suggests that, at parturition, the state of negative EB associated with the onset of milk synthesis may be partly responsible for the reduction of plasma leptin. To test this hypothesis, cows were either never milked after parturition (non-lactating) or milked thrice daily (lactating). When cows were studied at week +1 and +4 , the lactating group produced $30 \cdot 8 \pm 2 \cdot 4$ and $33 \cdot 7 \pm 4 \cdot 6 \mathrm{~kg} /$ day of $4 \%$ fat-corrected milk respectively. As expected, this experimental manipulation caused dramatic differences in $\mathrm{EB}$ after parturition, with non-lactating cows maintaining positive $\mathrm{EB}$ and $\mathrm{BC}$, and lactating cows being in negative EB and losing BC (Table 3). 
Table 1 Changes in energy-related variables during the transition period

Weeks relative to parturition ${ }^{\mathrm{a}}$

\begin{tabular}{|c|c|c|c|c|c|c|c|c|c|}
\hline-4 & -1 & +1 & +3 & +8 & S.E. & STATE & PREG & LACT & E-LACT \\
\hline $13 \cdot 8$ & $12 \cdot 1$ & $17 \cdot 5$ & $21 \cdot 3$ & $23 \cdot 9$ & 0.9 & $0 \cdot 001$ & NS & 0.001 & $0 \cdot 01$ \\
\hline $20 \cdot 6$ & $19 \cdot 8$ & $30 \cdot 9$ & $37 \cdot 6$ & $42 \cdot 1$ & $1 \cdot 5$ & $0 \cdot 001$ & NS & 0.001 & $0 \cdot 01$ \\
\hline - & - & $41 \cdot 2$ & $49 \cdot 7$ & $42 \cdot 7$ & $1 \cdot 5$ & - & - & NS & $0 \cdot 001$ \\
\hline $6 \cdot 9$ & $5 \cdot 9$ & $-11 \cdot 3$ & $-10 \cdot 5$ & -0.5 & $1 \cdot 4$ & $0 \cdot 001$ & NS & 0.001 & NS \\
\hline $3 \cdot 6$ & $3 \cdot 7$ & $3 \cdot 4$ & $3 \cdot 0$ & $2 \cdot 9$ & $0 \cdot 1$ & $0 \cdot 001$ & NS & 0.001 & $0 \cdot 001$ \\
\hline
\end{tabular}

Variables

Dry matter intake $(\mathrm{kg} /$ day)

Energy intake (Mcal/day)

Milk yield $(\mathrm{kg} / \text { day })^{\mathrm{c}}$

Energy balance (Mcal/day)

Body condition score

1

${ }^{a}$ Multiparous cows $(n=8)$ were studied during the period between 28 days before and 56 days after parturition. Week -4 corresponds to day -28 through -22 , week -1 to day -8 through -2 , week +1 to day +2 through +8 , week +3 to day +18 through +25 and week +8 to day +50 through +57 .

${ }^{b}$ Linear contrasts were: STATE, physiological state (week -4 and -1 vs week $+1,+3$ and +8 ); PREG, stage of pregnancy (week -4 vs -1 ); LACT, stage of lactation (week +1 and +3 vs week +8 ); E-LACT, early lactation (week +1 vs +3 ). Type I error probability where NS $=$ non-significant, $P>0 \cdot 05$.

'Expressed as $4 \%$ fat-corrected milk. Cows did not produce milk during pregnancy and therefore STATE and PREG contrasts do not apply.

Consistent with the EB data, lactating cows had lower plasma concentrations of insulin and glucose and higher plasma concentrations of GH and NEFA than nonlactating cows (Table 3; $P<0 \cdot 001$ ). Lactating cows also had lower plasma concentration of leptin than non-lactating
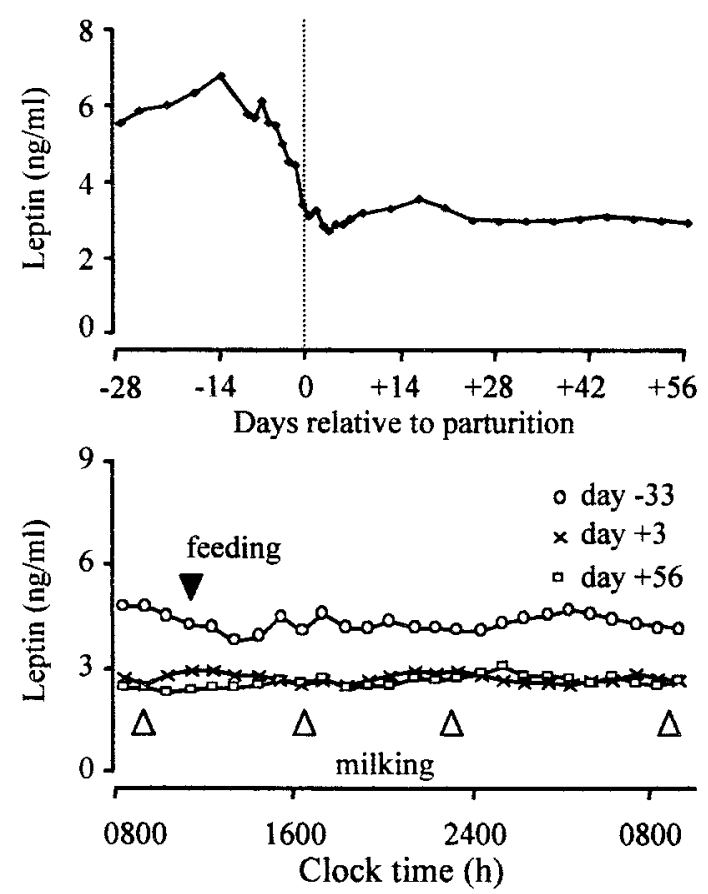

Figure 2 (Top panel) Changes in the concentration of plasma leptin during the periparturient period. Eight multiparous dairy cows were studied during the period between 28 days before and 56 days after parturition (day -28 to +56 ). The day of parturition is indicated by a vertical line. The concentration of plasma leptin was measured by a homologous RIA. The pooled standard error was $0.3 \mathrm{ng} / \mathrm{ml}$. (Bottom panel) The concentration of plasma leptin was measured at hourly intervals on day -33 , day +3 and day +56 relative to parturition. The open arrow heads indicate the times of milking and the solid arrow head the time of feeding. Lighting was provided between 0600 and $2300 \mathrm{~h}$. The pooled standard error was $0 \cdot 1 \mathrm{ng} / \mathrm{ml}$. cows $(P<0 \cdot 001)$. In contrast, the plasma concentration of cortisol did not differ between treatments. Effects of treatment were constant across times for all variables measured (time and treatment $\times$ time, $P>0 \cdot 05$ ). At week +1 , the plasma concentration of leptin was positively correlated with plasma concentrations of glucose and insulin $\left(\mathrm{R}^{2}=0.7\right.$ and 0.6 respectively, $P<0.001$; Fig. 4), and negatively correlated with the plasma concentrations of $\mathrm{GH}$ and NEFA $\left(\mathrm{R}^{2}=0 \cdot 5\right.$ for both, $\left.P<0 \cdot 01\right)$. Similar correlations were observed at week +4 (data not shown). Overall, these data demonstrate that the onset of an energy deficit at parturition is partly responsible for the lower concentration of plasma leptin in early lactating dairy cows.

\section{Discussion}

Lactation is essential to the survival of mammals and represents a substantial transfer of energy from mother to offspring. This transfer is facilitated by numerous endocrine and cellular adaptations. For example, elevated concentration of plasma $\mathrm{GH}$ in early lactating ruminants induces metabolic adaptations in liver, skeletal muscle and adipose tissue that promote partitioning of glucose to the mammary gland (Bell 1995, Vernon \& Pond 1997, Bauman 2000). Leptin, because of its role in the regulation of feed intake and energy disposition, could also participate in the co-ordination of metabolism during the transition from pregnancy to lactation. There is, however, no information on the dynamics of plasma leptin during the periparturient period in dairy cattle.

We now show that, as in rodents and humans (Kawai et al. 1997, Brogan et al. 1999, Butte et al. 1999, Woodside et al. 2000), the transition from pregnancy to lactation in dairy cows is associated with a reduction in the plasma concentration of leptin. This similarity exists despite the use of different strategies by these species to accommodate the energy needs of early lactation. For example, in this study, mobilization of endogenous lipids was estimated to 
Table 2 Changes in plasma metabolites and hormones during the transition period

\begin{tabular}{|c|c|c|c|c|c|c|c|c|c|c|}
\hline & \multicolumn{6}{|c|}{ Weeks relative to parturition ${ }^{a}$} & \multicolumn{4}{|c|}{ Significance of contrast ${ }^{b}$} \\
\hline & -4 & -1 & +1 & +3 & +8 & S.E. & STATE & PREG & LACT & E-LACT \\
\hline \multicolumn{11}{|l|}{ Variables } \\
\hline NEFA $(\mu \mathrm{M})$ & 107 & 121 & 546 & 293 & 144 & 23 & $0 \cdot 001$ & NS & $0 \cdot 001$ & $0 \cdot 001$ \\
\hline Glucose (mg/dl) & 55 & 55 & 50 & 47 & 55 & 2 & NS & NS & NS & NS \\
\hline \multicolumn{11}{|l|}{ Hormones } \\
\hline $\mathrm{GH}(\mathrm{ng} / \mathrm{ml})$ & $6 \cdot 7$ & $6 \cdot 0$ & $8 \cdot 3$ & $8 \cdot 5$ & $8 \cdot 8$ & $0 \cdot 5$ & $0 \cdot 001$ & NS & NS & NS \\
\hline IGF-I (ng/ml) & 124 & 77 & 40 & 36 & 40 & 9 & $0 \cdot 001$ & $0 \cdot 001$ & NS & NS \\
\hline Cortisol (ng/ml) & $2 \cdot 6$ & $2 \cdot 4$ & $2 \cdot 3$ & $2 \cdot 8$ & $3 \cdot 1$ & 0.5 & NS & NS & NS & NS \\
\hline
\end{tabular}

a Multiparous cows $(n=8)$ were studied during the period between 28 days before and 56 days after parturition. Week -4 corresponds to day -28 through -22 , week -1 to day -8 through -2 , week +1 to day +2 through +8 , week +3 to day +18 through +25 and week +8 to day +50 through +57 .

b Linear contrasts were: STATE, physiological state (week -4 and -1 vs week $+1,+3$ and +8 ); PREG, stage of pregnancy (week -4 vs -1 ); LACT, stage of lactation (week +1 and +3 vs week +8 ); E-LACT, early lactation (week $+1 \mathrm{vs}+3$ ). Type I error probability where NS $=$ non-significant, $P>0 \cdot 05$.

meet approximately 33\% of the cow's energy requirements between parturition and the third week of lactation. In contrast, rodents rely primarily on increased feed intake (Barber et al. 1997, Bauman 2000) whereas women, with relatively little change in energy demand from late pregnancy to early lactation (Butte et al. 1999), do not need major adjustments in either intake or lipid mobilization. The postpartum reduction in plasma leptin in all three species may relate to the contrasting priorities of pregnancy and lactation (i.e. storage of energy during pregnancy compared with export during lactation).
The reduction in the plasma concentration of leptin was temporally associated with a $57 \%$ decrease in the abundance of leptin mRNA. In other species, additional factors have been shown to contribute to changes in plasma leptin during the periparturient period. In primates, the placenta synthesizes leptin and contributes to circulating leptin during late pregnancy (Masuzaki et al. 1997, Henson et al. 1999). In the mouse, the placenta secretes massive amounts of the soluble form of the leptin receptor, extending the half-life of leptin and accounting for much of the 30-fold greater concentration of leptin in late

\section{Weeks relative to parturition}

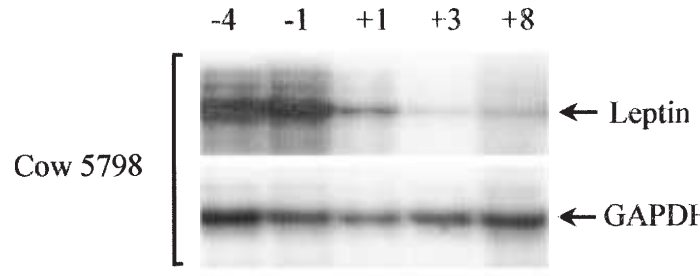

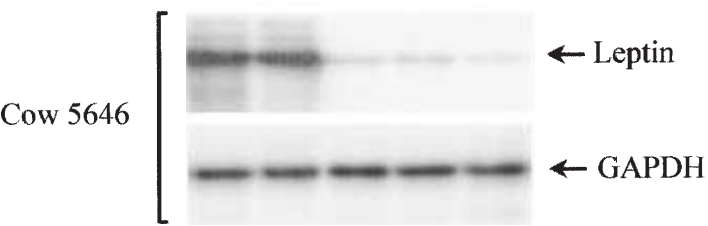

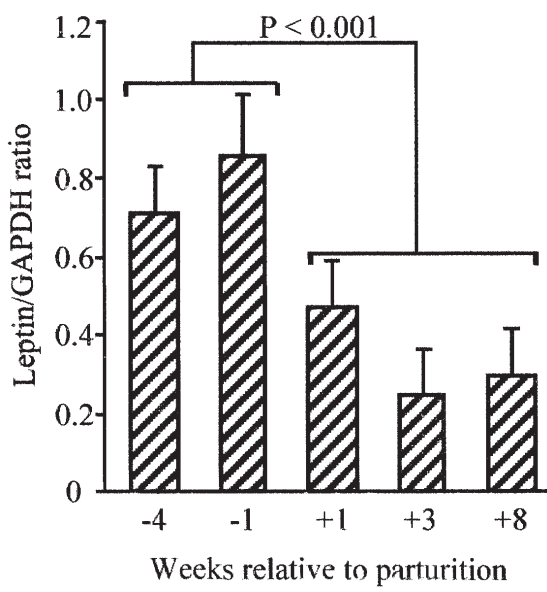

Figure 3 Expression of leptin mRNA in WAT during the periparturient period. Eight multiparous dairy cows were studied during the period between 28 days before and 56 days after parturition (day -28 to +56 ). (Left panel) Total RNA ( $2 \mu \mathrm{g}$ ) was obtained from WAT at the indicated times and analyzed simultaneously by a ribonuclease protection assay for the abundance of leptin and GAPDH mRNA. The sizes of the protected fragments are $253 \mathrm{bp}$ for leptin and $106 \mathrm{bp}$ for GAPDH. Data are from two representative animals. (Right panel) At each time, the leptin signal was normalized to the signal obtained with the GAPDH probe.

Normalized means \pm S.E. (eight cows) obtained at various times during the periparturient period are represented. The leptin signal was higher during pregnancy than during lactation (STATE, $P<0 \cdot 001$ ), but did not differ during pregnancy or during lactation (PREG, LACT and E-LACT, P>0.05). 
Table 3 Changes in energy-related variables and plasma metaboklites and hormones after parturition

\begin{tabular}{|c|c|c|c|c|}
\hline & \multicolumn{2}{|l|}{ Treatment $^{a}$} & \multirow[b]{2}{*}{ S.E. } & \multirow[b]{2}{*}{ Significance $^{b}$} \\
\hline & Non-lactating & Lactating & & \\
\hline \multicolumn{5}{|l|}{ Variables } \\
\hline \multicolumn{5}{|l|}{ Whole body energetics } \\
\hline Energy balance (Mcal/day) & $12 \cdot 1$ & $-16 \cdot 8$ & $4 \cdot 7$ & $0 \cdot 001$ \\
\hline$\Delta$ Body condition score ${ }^{\mathrm{c}}$ & $0 \cdot 1$ & $-0 \cdot 6$ & $0 \cdot 2$ & $0 \cdot 001$ \\
\hline \multicolumn{5}{|l|}{ Plasma concentration } \\
\hline Glucose (mg/dl) & 59 & 34 & 6 & $0 \cdot 001$ \\
\hline NEFA $(\mu M)^{\mathrm{c}}$ & 218 & 883 & 121 & $0 \cdot 001$ \\
\hline Leptin (ng/ml) & $5 \cdot 6$ & $2 \cdot 9$ & $1 \cdot 4$ & $0 \cdot 001$ \\
\hline Insulin (ng/ml) & $1 \cdot 9$ & $0 \cdot 3$ & $0 \cdot 5$ & $0 \cdot 001$ \\
\hline Cortisol (ng/ml) & $1 \cdot 5$ & $1 \cdot 2$ & $1 \cdot 0$ & NS \\
\hline $\mathrm{GH}(\mathrm{ng} / \mathrm{ml})$ & $2 \cdot 0$ & $4 \cdot 6$ & $1 \cdot 0$ & $0 \cdot 001$ \\
\hline
\end{tabular}

\footnotetext{
${ }^{a}$ After parturition, cows were either milked three times per day (lactating, $n=7$ ) or never milked (non-lactating, $n=7$ ). Cows were studied between day 5 and 11 (week +1 ) or between day 26 and 33 $($ week +4$)$. Overall averages are presented because the effects of time and time $\times$ treatment were not significant.

bType I error probability where NS= non-significant, $P>0 \cdot 05$.

${ }^{\mathrm{c}} \Delta$ Body condition score $=$ change in body condiiton score between week +1 and week +3 .
}

pregnant than in non-pregnant animals (Gavrilova et al. 1997). However, leptin is not expressed in ovine or bovine placenta at any stage of pregnancy (R A Ehrhardt, unpublished data). Moreover, the nearly identical concentrations of plasma leptin in late pregnant and postparturient, non-lactating cows indicate that loss of the placenta has no impact on leptin dynamics. Therefore, reduced synthesis of leptin in WAT is largely responsible for the lower concentration of plasma leptin in early lactating dairy cows.

In all species, plasma concentration of leptin is increased by overall adiposity, representing the positive effects of total mass of WAT and adipocyte hypertrophy (Friedman \& Halaas 1998, Ahima \& Flier 2000, Delavaud et al. 2000, Ehrhardt et al. 2000). In addition, undernutrition decreases and overfeeding increases circulating levels of leptin, well before significant changes in the mass of WAT occurs (MacDougald et al. 1995, Kolaczynski et al. 1996a, 1997, Blache et al. 2000). Our data suggest that the interplay between nutrition and adiposity accounts for most of the changes in plasma leptin in the periparturient dairy cow. Thus, around parturition, onset of an energy deficit causes a reduction in the concentration of circulating leptin. With advancing lactation, however, other factors become more important because the concentration of plasma leptin and leptin mRNA remained low despite improving EB. The most likely factor responsible for this uncoupling of plasma leptin concentration and EB is depletion of WAT as shown by lower $\mathrm{BC}$ scores with advancing lactation. It is also possible that failure to return to a threshold EB or other factors associated with lactation contribute to this uncoupling.

The significant correlations between the plasma concentrations of leptin, insulin, GH, glucose and NEFA could represent co-regulation by $\mathrm{EB}$, and perhaps a role for these factors in mediating the effect of $\mathrm{EB}$ on leptin synthesis. In support of the latter, insulin upregulates leptin expression in vivo and in vitro in rodent and human WAT (Saladin et al. 1995, Kolaczynski et al. 1996b, Boden et al. 1997), and in bovine WAT explants (Houseknecht et al. 2000). These effects of insulin are dependent on adequate uptake of glucose, suggesting that cellular energy availability is the primary factor regulating leptin synthesis (Mueller et al. 1998, Wellhoener et al. 2000). The CNS, via sympathetic innervation of WAT, could also play an important role in reducing leptin synthesis in early lactation: $\beta$-adrenergic signals are potent inhibitors of leptin expression in adipocytes (Hardie et al. 1996, Carulli et al. 1999), and ruminant WAT is particularly sensitive to their metabolic effects in early lactation (Vernon \& Pond 1997, Bauman 2000). Sustained periods of negative EB are also characterized by elevation in the plasma concentration of $\mathrm{GH}$ and by $\mathrm{GH}$ resistance in the liver, resulting in depressed plasma concentration of IGF-I (McGuire et al. 1995, Kobayashi et al. 1999). GH attenuates the ability of insulin and dexamethasone to stimulate leptin synthesis in bovine WAT explants (Houseknecht et al. 2000), but neither GH nor IGF-I has these effects in rat adipocytes (Hardie et al. 1996). Prolactin stimulates leptin synthesis in rats (Gualillo et al. 1999). The concentration of prolactin is increased around the time of parturition in dairy cows (Bell 1995) but the effects of prolactin on leptin synthesis have not been studied in ruminants. Additional studies are needed to ascertain the roles of these factors, and their interactions, in regulating leptin synthesis in the periparturient dairy cow.

The functional consequences of the periparturient reduction in plasma leptin in dairy cows remain to be 

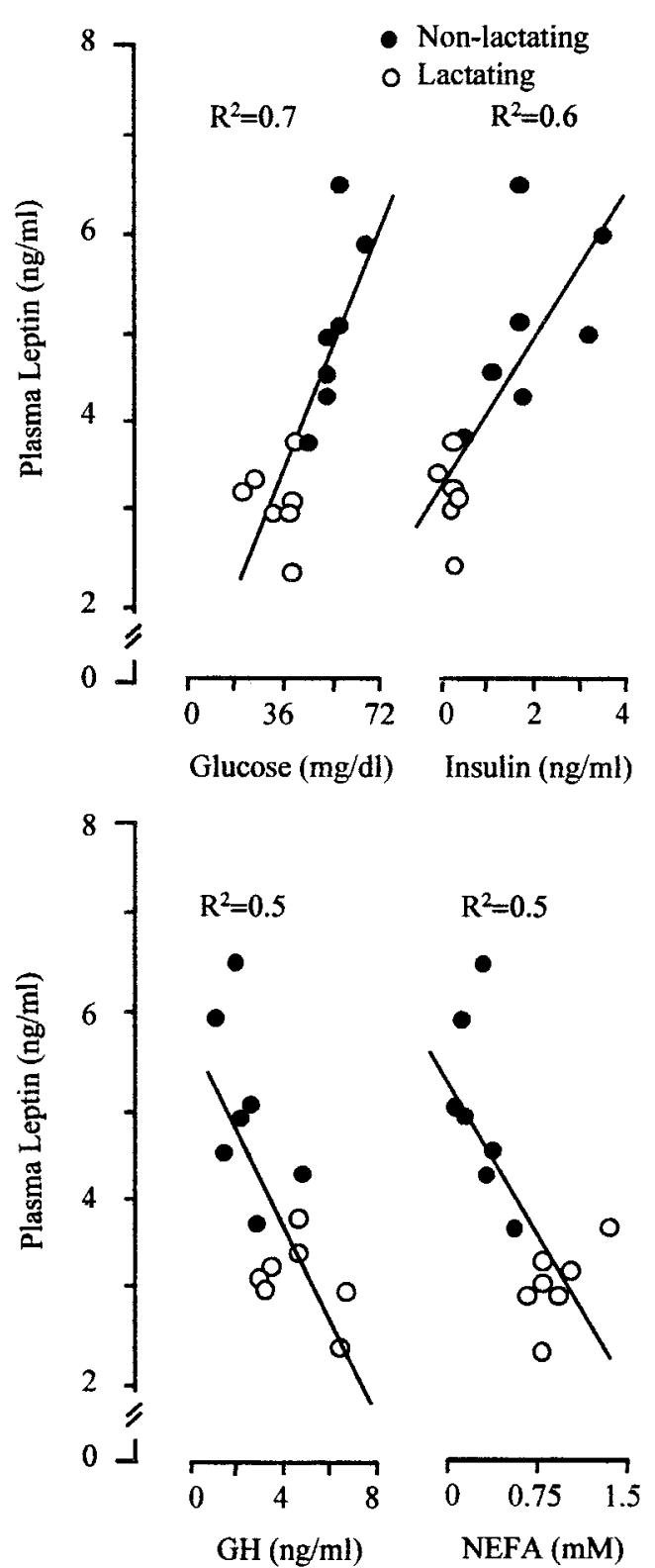

Figure 4 Relationship between the concentrations of leptin and other variables in plasma. Starting at parturition, cows were either milked thrice daily (Lactating) or never milked (Non-lactating). Plasma concentrations of leptin, glucose, insulin, GH and NEFA were measured during the first week after parturition. The relationships between the plasma concentration of leptin and the concentration of glucose $(y=0.8+0.07 x, P<0 \cdot 001)$, insulin $(y=3 \cdot 2+0 \cdot 8 x, P<0 \cdot 001), G H(y=5 \cdot 9-0 \cdot 5 x, P<0 \cdot 01)$ and NEFA $(y=5 \cdot 3-2 \cdot 1 x, P<0 \cdot 01)$ are illustrated.

characterized but, in the context of the energy deficit associated with early lactation, two possible benefits are immediately obvious. First, reduction in plasma leptin could promote a faster increase in voluntary feed intake. This effect, however, is likely to be minor because physical factors play an important role in constraining feed intake in early lactating ruminants (Ingvartsen \& Andersen 2000). Moreover, a $50 \%$ decline in plasma leptin may not stimulate appetite significantly given the modest anorexic effect of low doses of exogenous leptin in normal animals (Pelleymounter et al. 1995, Harris et al. 1998). A more immediate benefit of low plasma leptin concentration may be the induction and the co-ordination of the neuroendocrine adaptations responsible for partitioning energy towards essential functions, as shown in fasted rats (Ahima et al. 1996, 1999). Energy conservation is achieved by suppressing functions that are dispensable in the short term, such as reproduction and immunity. Both functions are depressed in early lactating dairy cows, but must be restored rapidly to avoid prolonged infertility and infectious diseases such as mastitis (Mallard et al. 1998, Butler 2000). The possibility that the leptin deficit of early lactation contributes to the development of these problems, as suggested by recent studies in fasted animals (Ahima et al. 1996, Finn et al. 1998, Lord et al. 1998, Nagatani et al. 2000), requires further studies.

\section{Acknowledgements}

We thank Ramona Slepetis for help in performing various RIAs, and Mary Partridge for help in collecting blood, milk and feed samples. This work was supported by the National Research Initiative Competitive Grant Program, USDA, CREES 00-35206-9352 (to Y R B) and by the Cornell University Agricultural Experiment Station.

\section{References}

Ahima RS \& Flier JS 2000 Leptin. Annual Review of Physiology 62 413-437.

Ahima RS, Dushay J, Flier SN, Prabakaran D \& Flier JS 1997 Leptin accelerates the onset of puberty in normal female mice. Journal of Clinical Investigation 99 391-395.

Ahima RS, Prabakaran D \& Flier JS 1998 Postnatal leptin surge and regulation of circadian rhythm of leptin by feeding. Journal of Clinical Investigation 101 1020-1027.

Ahima RS, Kelly J, Elmquist JK \& Flier JS 1999 Distinct physiologic and neuronal responses to decreased leptin and mild hyperleptinemia. Endocrinology 140 4923-4931.

Barber MC, Clegg RA, Travers MT \& Vernon RG 1997 Lipid metabolism in the lactating mammary gland. Biochimica et Biophysica Acta 1347 101-126.

Bauman DE 2000 Regulation of nutrient partitioning during lactation: homeostasis and homeorhesis revisited. In Ruminant Physiology, Digestion, Metabolism, Growth and Reproduction. Proceedings of the 9th International Symposium on Ruminant Physiology, pp 311-328. Ed. PB Cronje. New York: CABI Publishing.

Bauman DE \& Currie WB 1980 Partitioning of nutrients during pregnancy and lactation: a review of mechanisms involving homeostasis and homeorhesis. Journal of Dairy Science 63 1514-1529.

Beam SW \& Butler WR 1997 Energy balance and ovarian follicle development prior to the first ovulation postpartum in dairy cows receiving three levels of dietary fat. Biology of Reproduction $\mathbf{5 6}$ 133-142. 
Bell AW 1995 Regulation of organic nutrient metabolism during transition from late pregnancy to early lactation. Journal of Animal Science 73 2804-2819.

Bell AW \& Bauman DE 1997 Adaptations of glucose metabolism during pregnancy and lactation. Journal of Mammary Gland Biology and Neoplasia 2 265-278.

Blache D, Tellam RL, Chagas LM, Blackberry MA, Vercoe PE \& Martin GB 2000 Level of nutrition affects leptin concentrations in plasma and cerebrospinal fluid in sheep. Journal of Endocrinology 165 625-637.

Boden G, Chen X, Kolaczynski JW \& Polansky M 1997 Effects of prolonged hyperinsulinemia on serum leptin in normal human subjects. Journal of Clinical Investigation 100 1107-1113.

Boisclair Y, Bauman D, Bell A, Dunshea F \& Harkins M 1994 Nutrient utilization and protein turnover in the hindlimb of cattle treated with bovine somatotropin. Journal of Nutrition 124 664-673.

Boisclair YR, Wang J, Shi J, Hurst KR \& Ooi GT 2000 Role of the suppressor of cytokine signaling-3 (SOC3) in mediating the inhibitory effects of interleukin- $1 \beta$ on the growth hormonedependent transcription of the acid-labile subunit gene in liver cells. Journal of Biological Chemistry 275 3841-3847.

Brogan RS, Mitchell SE, Trayhurn P \& Smith MS 1999 Suppression of leptin during lactation: contribution of the suckling stimulus versus milk production. Endocrinology 140 2621-2627.

Butler WR 2000 Nutritional interactions with reproductive performance in dairy cattle. Animal Reproduction Science 60-61 449-457.

Butte NF, Hopkinson JM, Mehta N, Moon JK \& O'Brian Smith E 1999 Adjustments in energy expenditure and substrate utilization during late pregnancy and lactation. American Journal of Clinical Nutrition 69 299-307.

Carulli L, Ferrari S, Bertolini M, Tagliafico E \& Del Rio G 1999 Regulation of $o b$ gene expression: evidence for epinephrine-induced suppression in human obesity. Journal of Clinical Endocrinology and Metabolism 84 3309-3312.

Delavaud C, Bocquier F, Chilliard Y, Keisler DH, Gertler A \& Kann G 2000 Plasma leptin determination in ruminants: effect of nutritional status and body fatness on plasma leptin concentration assessed by a specific RIA in sheep. Journal of Endocrinology 165 519-526.

Ehrhardt RA, Slepetis RM, VanAmburgh ME, Siegal-Willot J, Bell AW \& Boisclair YR 2000 Development of a specific RIA to measure physiological changes of circulating leptin in cattle and sheep. Journal of Endocrinology 166 519-528.

Etherton TD \& Bauman DE 1998 Biology of somatotropin in growth and lactation of domestic animals. Physiological Reviews 78 745-761.

Finn PD, Cunningham MJ, Pau K-YF, Spies HG, Clifton DK \& Steiner RA 1998 The stimulatory effect of leptin in the neuroendocrine reproductive axis of the monkey. Endocrinology 139 4652-4662.

Flier JS 1998 What's in a name? In search of leptin's physiologic role. Journal of Clinical Endocrinology and Metabolism 83 1407-1413.

Friedman JM \& Halaas JL 1998 Leptin and the regulation of body weight in mammals. Nature 395 763-770.

Gavrilova O, Barr V, Marcus-Samuels B \& Reitman M 1997 Hyperleptinemia of pregnancy associated with the appearance of a circulating form of the leptin receptor. Journal of Biological Chemistry 272 30546-30551.

Gualillo O, Lago F, Garcia M, Menendez C, Senaris R, Casanueva FF \& Dieguez C 1999 Prolactin stimulates leptin secretion by rat white adipose tissue. Endocrinology 140 5149-5153.

Hardie LJ, Guilhot N \& Trayhurn P 1996 Regulation of leptin production in cultured mature white adipocytes. Hormone and Metabolic Research 28 685-689.

Harris RBS, Zhou J, Redmann SM Jr, Smagin GN, Smith SR, Rodgers E \& Zachwieja JJ 1998 A leptin dose-response study in obese $(o b / o b)$ and lean $(+/$ ?) mice. Endocrinology 139 8-19.
Henry BA, Goding JW, Alexander WS, Tilbrook AJ, Canny BJ, Dunshea F, Rao A, Mansell A \& Clarke IJ 1999 Central administration of leptin to ovariectomized ewes inhibits food intake without affecting the secretion of hormones from the pituitary gland: evidence for a dissociation of effects on appetite and neuroendocrine function. Endocrinology 140 1175-1182.

Henson MC, Castracane VD, O’Neil JS, Gimpel T, Swan KF, Green AE \& Shi W 1999 Serum leptin concentrations and expression of leptin transcripts in placental trophoblast with advancing baboon pregnancy. Journal of Clinical Endocrinology and Metabolism 84 2543-2549.

Houseknecht KL \& Bauman DE 1997 Regulation of lipolysis by somatotropin: functional alteration of adrenergic and adenosine signaling in bovine adipose tissue. Journal of Endocrinology 152 $465-475$.

Houseknecht KL, Portocarrero CP, Ji S, Lemenager R \& Spurlock ME 2000 Growth hormone regulates leptin gene expression in bovine adipose tissue: correlation with adipose IGF-1 expression. Journal of Endocrinology 164 51-57.

Ingvartsen KL \& Andersen JB 2000 Integration of metabolism and intake regulation: a review focusing on periparturient animals. Journal of Dairy Science 83 1573-1597.

Ji S, Willis GM, Scott RR \& Spurlock ME 1998 Partial cloning and expression of the bovine leptin gene. Animal Biotechnology 9 1-14.

Kawai M, Yamaguchi M, Murakami T, Shima K, Murata Y \& Kishi K 1997 The placenta is not the main source of leptin production in pregnant rat: gestational profile of leptin in plasma and adipose tissues. Biochemical and Biophysical Research Communications 240 798-802.

Kobayashi Y, Boyd CK, Bracken CJ, Lamberson WR, Keisler DH \& Lucy MC 1999 Reduced growth hormone receptor (GHR) messenger ribonucleic acid in liver of periparturient cattle is caused by a specific down-regulation of GHR $1 \mathrm{~A}$ that is associated with decreased insulin-like growth factor I. Endocrinology 140 3947-3954.

Kolaczynski JW, Considine RV, Ohannesian J, Marco C, Opentanova I, Nyce MR, Myint M \& Caro JF 1996a Responses of leptin to short-term fasting and refeeding in humans: a link with ketogenesis but not ketones themselves. Diabetes 45 1511-1515.

Kolaczynski JW, Nyce MR, Considine RV, Boden G, Nolan JJ, Henry R, Mudaliar SR, Olefsky J \& Caro JF 1996 b Acute and chronic effect of insulin on leptin production in humans. Diabetes 45 699-701.

Kolaczynski JW, Ohannesian JP, Considine RV, Marco CC \& Caro JF 1997 Response to leptin to short-term and prolonged overfeeding in humans. Journal of Clinical Endocrinology and Metabolism 81 4162-4165.

Lord GM, Matarese G, Howard JK, Baker RJ, Bloom SR \& Lechler RI 1998 Leptin modulates the T-cell immune response and reverses starvation-induced immunosuppression. Nature 394 897-900.

MacDougald OA, Hwang C-S, Fan H \& Lane MD 1995 Regulated expression of the obese gene product (leptin) in white adipose tissue and 3T3-L1 adipocytes. PNAS 92 9034-9037.

McGuire MA, Bauman DE, Dwyer DA \& Cohick WS 1995 Nutritional modulation of the somatotropin/insulin-like growth factor system: response to feed deprivation in lactating cows. Journal of Nutrition 125 493-502.

Mallard BA, Dekkers JC, Ireland MJ, Leslie KE, Sharif S, Vankampen CL, Wagter L \& Wilkie BN 1998 Alteration in immune responsiveness during the peripartum period and its ramification on dairy cow and calf health. Journal of Dairy Science 81 585-595.

Masuzaki H, Ogawa Y, Sagawa N, Hosoda K, Matsumoto T, Mise H, Nishimura H, Yoshimasa Y, Tanaka I, Mori T \& Nakao K 1997 Nonadipose tissue production of leptin: leptin as a novel placentaderived hormone in humans. Nature Medicine 3 1029-1033.

Mueller WM, Gregoire FM, Stanhope KL, Mobbs CV, Mizuno TM, Warden CH, Stern JS \& Havel PJ 1998 Evidence that glucose metabolism regulates leptin secretion from cultured rat adipocytes. Endocrinology 139 551-558. 
Nagatani S, Zeng Y, Keisler DH, Foster DL \& Jaffe CA 2000 Leptin regulates pulsatile luteinizing hormone and growth hormone secretion in the sheep. Endocrinology 141 3965-3975.

National Research Council 1989 Nutrient Requirements of Dairy Cattle, revised ed. 6. Washington, DC: National Academy Press.

Pelleymounter MA, Cullen MJ, Baker MB, Hecht R, Winters D, Boone T \& Collins F 1995 Effects of the obese gene product on body weight regulation in ob/ob mice. Science $269540-543$.

Saladin R, De Vos P, Guerre-Millo M, Leturque A, Girard J, Staels B \& Auwerx J 1995 Transient increase in obese gene expression after food intake or insulin administration. Nature 377 527-529.

Schoeller DA, Cella LK, Sinha MK \& Caro JF 1997 Entrainment of the diurnal rhythm of plasma leptin to meal timing. Journal of Clinical Investigation 100 1882-1887.

Schwartz MW, Woods SC, Porte D Jr, Seeley RJ \& Baskin DG 2000 Central nervous system control of food intake. Nature 404 661-671.
Vernon RG \& Pond CM 1997 Adaptations of maternal adipose tissue to lactation. Journal of Mammary Gland Biology and Neoplasia 2 231-241.

Wellhoener P, Fruehwald-Schultes B, Kern W, Dantz D, Kerner W, Born J, Fehm HL \& Peters A 2000 Glucose metabolism rather than insulin is a main determinant of leptin secretion in humans. Journal of Clinical Endocrinology and Metabolism 85 1267-1271.

Woodside B, Abizaid A \& Walker C 2000 Changes in leptin levels during lactation: implications for lactational hyperphagia and anovulation. Hormones and Behavior 37 353-365.

Zhang Y, Proenca R, Maffei M, Barone M, Leopold L \& Friedman JM 1994 Positional cloning of the mouse obese gene and its human homologue. Nature 372 425-432.

Received 31 January 2001

Accepted 9 July 2001 